Nr 3(66), 2020, s. 157-169

https://doi.org/10.12797/Politeja.17.2020.66.11

Wawrzyniec BANACH D

Uniwersytet Jagielloński

wawrzyniec.banach@student.uj.edu.pl

\title{
UNIA EUROPEJSKA WOBEC BAŁKANÓW ZACHODNICH W KONTEKŚCIE KRYZYSU MIGRACYJNEGO W LATACH 2015-2019
}

ABSTRACT European Union towards Western Balkans in the Context of Migration Crisis 2015-2019

The aim of the article is to analyse the actions taken by the European Union towards the Western Balkans in the context of the migration crisis. The study assumes that the migration crisis was an important factor accelerating the accession process of the Western Balkan countries to the European Union. In order to fulfil the research goal, an analysis of sources (European Union documents) was conducted. The paper uses elements of the theory of the regional security complex as a theoretical framework. Firstly, the activities of the European Union before the migration crisis are discussed. Next, the paper focuses on presenting the course of the crisis on the Western Balkan route. The further part of the study discusses the actions taken by the EU towards the countries of the Western Balkans in response to the migration crisis.

Keywords: Western Balkans, European Union, migration crisis, external actions of the European Union

Słowa kluczowe: Bałkany Zachodnie, Unia Europejska, kryzys migracyjny, działania zewnętrzne Unii Europejskiej 


\section{UWAGI WSTĘPNE}

Bałkany są często nazywane przez badaczy stosunków międzynarodowych „miękkim podbrzuszem" Europy - w nawiązaniu do słów Winstona Churchilla, który użył tego określenia w odniesieniu do Bałkanów podczas końcowej fazy II wojny światowej ${ }^{1}$. Termin „Bałkany Zachodnie” ma węższe znaczenie w sensie geograficznym i politycznym. Był on wykorzystywany przez Organizację Traktatu Północnoatlantyckiego (NATO) i Unię Europejską (UE) od wczesnych lat 90. XX w., po rozpadzie Socjalistycznej Federacyjnej Republiki Jugosławii. Za Bałkany Zachodnie w terminologii stosowanej obecnie przez instytucje UE uznaje się sześć państw Europy Południowo-Wschodniej, objętych polityką rozszerzenia UE: Republikę Albanii, Bośnię i Hercegowinę, Czarnogórę, Republikę Kosowa, Republikę Macedonii Północnej i Republikę Serbii. Wcześniej określenie to stosowano także wobec Słowenii i Chorwacji, które przystąpiły do UE odpowiednio 1 maja 2004 r. i 1 lipca 2013 r.

Relacje między UE a Bałkanami Zachodnimi są przedmiotem zainteresowania wielu politologów i badaczy stosunków międzynarodowych. Większość badań skupia się na perspektywie członkostwa państw tego regionu w UE oraz procesie europeizacji na tym obszarze. Niektórzy badacze (m.in. Emilio $\mathrm{Cocco}^{2}$ i Alice Greider ${ }^{3}$ ) analizowali stosunki UE-Bałkany Zachodnie w kontekście kryzysu migracyjnego i polityki rozszerzenia. Wymienieni autorzy krytykują działania UE wobec Bałkanów Zachodnich w tej perspektywie, uważając je za krótkoterminowe. Niniejszy tekst wpisuje się w tę linię krytyki, jednak zwraca też uwagę na strategię eksternalizacji, która nie jest działaniem doraźnym. Badacze często wskazują akcesję państw bałkańskich jako kluczowy cel strategiczny UE $U^{4}$. Renata Podgórzańska zauważyła, że kryzys migracyjny mógł mieć wpływ na dynamizację procesu integracji UE z państwami Bałkanów Zachodnich ${ }^{5}$. W artykule podjęto próbę identyfikacji innych celów strategicznych UE, które służą poszerzeniu strefy wpływów bez konieczności rozszerzania organizacji.

Celem niniejszego opracowania jest analiza działań UE wobec państw należących do regionu Bałkanów Zachodnich w kontekście kryzysu migracyjnego w latach

M. Dymarski, „Miękkie podbrzusze Europy” - Batkany w nowoczesnych stosunkach międzynarodowych, [w:] Batkany. Przesztość - teraźniejszość - przysztość, red. M. Podolak, Lublin 2013, s. 347, Wprowadzenie do Studiów Wschodnioeuropejskich, t. 1.

2 E. Cocco, Where Is the European Frontier? The Balkan Migration Crisis and Its Impact on Relations between the EU and the Western Balkans, „European View” 2017, Vol. 16, nr 2.

3 A. Greider, Outsourcing Migration Management: The Role of the Western Balkans in the European Refugee Crisis, 17 VIII 2017, [online] http://www.migrationpolicy.org/article/outsourcing-migrationmanagement-western-balkans-europes-refugee-crisis, 20 XII 2019.

4 E. Bujwid-Kurek, Państwa o proweniencji jugostowiańskiej w procesie rozszerzania Unii Europejskiejrefleksja politologiczna, „Politeja” 2019, Vol. 15, nr 54, s. 7.

5 R. Podgórzańska, Kryzys migracyjny w Unii Europejskiej z perspektywy Batkanów Zachodnich, „Rocznik Integracji Europejskiej” 2018, nr 11, s. 295-313. 
2015-2019. Na potrzeby tego artykułu za początek kryzysu migracyjnego uznaje się rok 2015, ze względu na szczególne nasilenie migracji na szlaku zachodniobałkańskim. W analizie dokonano następującego założenia: kryzys migracyjny był czynnikiem wzmacniającym zaangażowanie UE w Bałkanach Zachodnich. Aby zrealizować wspomniany cel, dokonano analizy źródeł w postaci dokumentów oraz komunikatów prasowych UE. Jako ramy teoretyczne wykorzystano elementy regionalnego kompleksu bezpieczeństwa (Regional security complex, RSCT) autorstwa Barry'ego Buzana i Olego Wrevera ${ }^{6}$. Przedmiotem analizy były relacje między regionalnym kompleksem bezpieczeństwa tworzonym przez UE a regionem Bałkanów Zachodnich. W pierwszej kolejności omówiono działania UE przed kryzysem migracyjnym, następnie skupiono się na przedstawieniu przebiegu kryzysu na szlaku zachodniobałkańskim. W dalszej części opracowania omówiono działania podjęte przez UE wobec państw Bałkanów Zachodnich w reakcji na kryzys migracyjny oraz przedstawiono konkluzje.

\section{POLITYKA PRZED KRYZYSEM MIGRACYJNYM}

Nie sposób analizować działań UE wobec Bałkanów Zachodnich bez przedstawienia szerszego kontekstu i genezy jej aktywności w tym regionie. $\mathrm{Z}$ racji swojego położenia państwa bałkańskie niemal od początku funkcjonowania tej organizacji stanowiły przedmiot jej zainteresowania. W 1999 r. niemiecka prezydencja w Radzie Unii Europejskiej zainicjowała Pakt stabilności dla Europy Południowo-Wschodniej (Stability Pact for South Eastern Europe) - szeroką inicjatywę obejmującą wszystkie kluczowe podmioty na arenie międzynarodowej, która miała przyczynić się do rozwijania dyplomacji prewencyjnej i stworzenia trwałego pokoju w regionie ${ }^{7}$.

W 2000 r. rozpoczęto realizację nowej inicjatywy: Procesu stabilizacji i stowarzyszenia (Stabilisation and Association Process, SAP), stanowiącego ramy stosunków UE z państwami tego regionu. Państwa z obszaru postjugosłowiańskiego oraz Albania, które aspirowały do członkostwa w UE, zobowiązały się w jego ramach do rozwijania współpracy między sobą, co miało pomóc w rozwiązaniu konfliktów i problemów na etapie przedakcesyjnym. Celami UE były wówczas odtworzenie relacji między sąsiadującymi państwami oraz wytworzenie więzi i poczucia wspólnoty między poszczególnymi narodami w regionie. Z partnerami uczestniczącymi w procesie UE podpisywała Porozumienia o stabilizacji i stowarzyszeniu (Stability and Association Agreement, SAA) ${ }^{8}$. Można

6 B. Buzan, O. Waever, Regions and Powers. The Structure of International Security, Cambridge 2003, s. 1, Cambridge Studies in International Relations, 91.

7 P. Sokołowska, RFN-Unia Europejska i Pakt Stabilności dla Europy Potudniowo-Wschodniej, „Rocznik Integracji Unii Europejskiej" 2007, nr 2, s. 206-208.

$8 \quad$ K. Koźbial, Unia Europejska jako czynnik stabilizacyjny na Batkanach. Stan obecny i wyzwania na przysztość, [w:] Unia Europejska jako wspótczesny aktor stosunków międzynarodowych, red. J. Knopek, Toruń 2009, s. 373-375. 
więc zaryzykować stwierdzenie, że - w dużym uproszczeniu - celem UE była wówczas regionalizacja top-down'.

Kolejnym przełomowym wydarzeniem dla relacji UE-Bałkany Zachodnie był Szczyt Rady Europejskiej w Salonikach w czerwcu 2003 r. Wskazano na nim, że droga do członkostwa jest otwarta dla państw regionu, jeżeli spełnią one określone warunki ${ }^{10}$, sprecyzowane m.in. w dokumencie „The Thessaloniki Agenda for the Western Balkans - Moving towards European Integration”. Podkreślono w nim rolę wspierania dialogu i wzmacniania współpracy w ramach wspólnej polityki zagranicznej i bezpieczeństwa (WPZiB), zwalczania przestępczości zorganizowanej i współpracy wewnętrznej. Za szczególnie istotne uznano walkę z przemytem ludzi oraz zwalczanie nielegalnej migracji. W odniesieniu do tej ostatniej kwestii zalecono pogłębianie współpracy poszczególnych jednostek administracyjnych w państwach Bałkanów Zachodnich z imigracyjnymi oficerami łącznikowymi UE oraz konieczność podpisywania umów o readmisji pomiędzy państwami regionu, a także zawierania umów z państwami trzecimi spoza regionu ${ }^{11}$.

W lutym 2008 r. wspomniany Pakt stabilności dla Europy Południowo-Wschodniej zastąpiła Rada Współpracy Regionalnej (Regional Cooperation Council). Jej głównymi zadaniami miały być koordynacja i konsolidacja współpracy regionalnej oraz tworzenie współpracy o charakterze ponadnarodowym. W'śród pięciu obszarów priorytetowych znalazły się: rozwój gospodarczy i społeczny, infrastruktura i energia, wymiar sprawiedliwości i sprawy wewnętrzne, współpraca w dziedzinie bezpieczeństwa, doskonalenie jakości kapitału ludzkiego ${ }^{12}$.

W kolejnych latach proces rozszerzenia znacznie spowolnit. Z jednej strony było to spowodowane problemami wewnętrznymi państw Bałkanów Zachodnich, a z drugiej wynikało z problemów wewnętrznych UE wywołanych kryzysem gospodarczym i będącej ich rezultatem rezygnacji $\mathrm{z}$ aktywnej polityki w tym regionie ${ }^{13}$. Przełomowych zmian nie spodziewano się też w trakcie nowej kadencji Komisji Europejskiej (KE). W 2014 r. przewodniczący KE Jean-Claude Juncker oświadczył, że w trakcie jego kadencji nie będzie nowego rozszerzenia UE. Długotrwałą bierność polityki UE w regionie wykorzystali inni aktorzy na arenie międzynarodowej, tacy jak Rosja, Turcja, Chiny i Iran, którym udało się w znacznym zakresie rozszerzyć swoje wpływy w państwach Bałkanów Zachodnich ${ }^{14}$.

9 J. Paszkiewicz, Wspótpraca regionalna na Batkanach Zachodnich z perspektywy Unii Europejskiej. Przestanki iprzeszkody, [w:] Batkany Zachodnie między przesztością a przysztością, red. P. Chmielewski, S.L. Szczesio, Łódź 2013, s. 518, Batkany na Przetomie XX/XXI Wieku, 3.

10 M. Szpala, Nowe otwarcie w stosunkach Unia Europejska - Batkany Zachodnie, „Komentarze OSW” 2018, 267, s. 2.

11 Council of the European Union, Council Conclusions on the Western Balkans, $2518^{\text {th }}$ Council meeting - External Relations, Luxembourg, 16 VI 2003, s. 10-16.

12 P. Olszewski, Batkany Zachodnie w polityce Unii Europejskiej, „Myśl Ekonomiczna i Polityczna” 2010, 1(28), s. 178-179.

13 Tamże, s. 3.

$14 \quad$ M. Szpala, Nowe otwarcie..., s. 4. 


\section{BAŁKANY ZACHODNIE PODCZAS KRYZYSU MIGRACYJNEGO}

W 2015 r. odnotowano rekordowy wzrost nielegalnych przekroczeń granicy na Bałkanach Zachodnich: 764033 razy $^{15}$. Migranci przybyli do Grecji i chcieli przedostać się do Europy Zachodniej przez kraje byłej Republiki Jugosławii, zwłaszcza Serbię i Macedonię. Byli oni głównie narodowości syryjskiej, a w dalszej kolejności irackiej i afgańskiej. Na granicy chorwacko-serbskiej i serbsko-macedońskiej wprowadzono szczegółowe kontrole, wcześniej Węgry zbudowały zasieki na granicy z Serbią. W marcu 2016 r. pod naciskiem Węgier i Austrii szlak bałkański został praktycznie zamknięty. W rezultacie liczba nielegalnych przekroczeń granicy spadła w 2016 r. do 130325 , w kolejnym do 12 179, zaś w 2018 r. zmniejszyła się dwukrotnie w porównaniu do roku poprzedniego $(5869)^{16}$.

W 2019 r. sytuacja na szlaku zachodniobałkańskim uległa zmianie, ponieważ odwrócił się utrzymujący się od trzech lat trend spadkowy. W sierpniu na tej trasie zarejestrowano prawie 400 przypadków nielegalnego przekroczenia granicy. Łącznie w ciągu 11 miesięcy (od stycznia do listopada) odnotowano 10619 takich przypadków, czyli ponad 90\% więcej niż rok wcześniej. Inaczej niż w 2015 r. największą część migrantów wykrytych na tej trasie stanowili obywatele Afganistanu (4810 osób) ${ }^{17}$.

W 2019 r. migranci zaczęli poszukiwać nowej trasy przez Bośnię i Hercegowinę. W pierwszej połowie roku znaczny wzrost liczby migrantów, w tym osób poszukujących azylu, odnotowało też Biuro Wysokiego Komisarza Narodów Zjednoczonych do spraw Uchodźców (Office of the United Nations High Commissioner for Refugees, UNHCR $)^{18}$.Zmiana dotyczyła nie tylko liczby napływających osób, lecz także wyboru trasy w obrębie szlaku zachodniobałkańskiego. Ze względu na stosunkowo słabą kontrolę częściej wybierano tę biegnącą przez granicę Bośni i Hercegowiny z Chorwacją (o długości $923 \mathrm{~km}$ ). W mediach społecznościowych przejście przez Bośnię i Hercegowinę określane było mianem bośniackiej luki $i^{19}$.

15 Wzrost liczby prób nielegalnego przekroczenia granic na zachodnim szlaku bałkańskim można zaobserwować już od 2011 r.; podjęto ich wówczas 4650. W 2012 r. liczba ta wzrosła do 6390, a w 2013 r. prawie potroiła się w porównaniu z poprzednim rokiem. W 2014 r. na szlaku nielegalnie przekroczono granicę 43357 razy. Migratory Routes, Frontex, [online] https://frontex.europa.eu/along-eu-borders/migratory-routes/western-balkan-route/, 20 XII 2019.

16 Migratory Map, Frontex, [online] https://frontex.europa.eu/along-eu-borders/migratory-routes/ western-balkan-route/, 20 XII 2019.

17 Innymi popularnymi krajami pochodzenia były kolejno: Syria (1831 osób), Irak (1034), Iran (771) i Pakistan (482). Tamże.

18 Population Trends, UNHCR, [online] https://www.unhcr.org/see/about-us/population-trends, 20 XII 2019.

19 M. Antosiewicz, Zaczyna się nowa fala migracji do Europy. Imigranci wrócili na szlak batkański, Newsweek, 9 VII 2019, [online] https://www.newsweek.pl/swiat/nowa-fala-migracji-do-europy-imigranci-wrocili-na-szlak-balkanski/49k700p, 20 XII 2019. 


\section{DZIAŁANIA UNII EUROPEJSKIEJ PODCZAS KRYZYSU}

W związku z kryzysem migracyjnym UE w znacznym stopniu ograniczyła krytykę kontrowersyjnych działań bałkańskich liderów i skupiła się na wzmocnieniu współpracy z nimi w celu powstrzymania wzmożonej migracji do $U^{20}$.

Jednym z pierwszych działań podjętych przez UE i partnerów z Bałkanów Zachodnich było przyjęcie 17-punktowego planu działania w sprawie szlaku zachodniobałkańskiego podczas spotkania przywódców w Brukseli w siedzibie KE 25 października 2015 r. Plan miał na celu usprawnić współpracę między państwami położonymi wzdłuż szlaku zachodniobałkańskiego i pomóc rozwiązać kryzys uchodźczy w regionie. W jego ramach uwzględniono m.in. takie priorytety, jak: konieczność ciągłej wymiany informacji, ograniczenie przemieszczania migrantów do kolejnych granic, wspieranie uchodźców i zapewnienie im schronienia oraz podstawowych środków do życia, współpraca z UNHCR w celu zapewnienia dodatkowych miejsc przyjęć na szlaku zachodniobałkańskim, zarządzanie ruchami migracyjnymi i ochroną granic, zwalczanie przemytu ludzi, informowanie uchodźców o przysługujących im prawach oraz ogólne monitorowanie sytuacji. W obrębie tych zagadnień w planie znalazło się również kilka punktów poświęconych poszczególnym państwom bałkańskim. Zgodzono się na wzmocnienie współpracy dotyczącej ochrony granicy między Macedonią a Grecją przy wsparciu UNHCR oraz granic zewnętrznych Grecji, Macedonii i Albanii. W tym działaniu Frontex (Europejska Agencja Zarządzania Współpracą Operacyjną na Zewnętrznych Granicach Państw Członkowskich Unii Europejskiej, obecnie Europejska Agencja Straży Granicznej i Przybrzeżnej ${ }^{21}$ ) miał pomóc w rejestracji migrantów w Grecji, a także być zaangażowany w monitorowanie sytuacji i pobieranie odcisków palców na granicy serbsko-chorwackiej ${ }^{22}$. Na podstawie wymienionych priorytetów można zaryzykować stwierdzenie, że celem nadrzędnym UE było zatrzymanie migrantów w „strefie buforowej”, jaką są Bałkany Zachodnie, i przejęcie kontroli nad falą migracyjną przemieszczającą się szlakiem zachodniobałkańskim.

Jednocześnie 15 grudnia 2015 r. Rada Unii Europejskiej przyjęła konkluzje w sprawie polityki rozszerzenia UE wobec Turcji, Czarnogóry oraz Serbii, a także procesu stabilizacji i stowarzyszenia UE-Bałkany Zachodnie (Macedonia, Albania, Bośnia i Hercegowina oraz Kosowo). Warto zauważyć, że podczas posiedzenia Rada wyraziła szczególne uznanie dla Turcji, Serbii i Macedonii za ich działania na rzecz rozwiązania

20 M. Szpala, Nowe otwarcie..., s. 4.

21 Europejską Agencję Straży Granicznej i Przybrzeżnej (Frontex) ustanowiono Rozporządzeniem Parlamentu Europejskiego i Rady (UE) 2016/1624 z dnia 14 września 2016 r. w sprawie Europejskiej Straży Granicznej i Przybrzeżnej oraz zmieniajace rozporządzenie Parlamentu Europejskiego i Rady (UE) 2016/399 i uchylające rozporzadzenie (WE) nr 863/2007 Parlamentu Europejskiego i Rady, rozporzadzenie Rady (WE) nr 2007/2004 i decyzje Rady 2005/267/WE, Dz.U. UE, L 251, 16 IX 2016, s. 1.

22 European Commission, Meeting on the Western Balkans Migration Route: Leaders Agree on 17-Point Plan of Action, 25 X 2015, [online] https://ec.europa.eu/commission/presscorner/detail/en/ IP_15_5904, 27 XII 2019. 
problemów związanych z kryzysem migracyjnym, co pokazuje, że UE aktywnie próbowała oddziaływać na państwa ościenne i rozwijać z nimi współpracę w obrębie swojej polityki migracyjnej i ochrony granic zewnętrznych ${ }^{23}$.

Z kolei KE 21 grudnia 2015 r. ze względu na trudną sytuację na szlaku zachodniobałkańskim zdecydowała o rozszerzeniu finansowania pomocy humanitarnej w ramach powstałego w $2014 \mathrm{r}$. regionalnego funduszu powierniczego UE w odpowiedzi na kryzys w Syrii (EU Regional Trust Fund in Response to the Syrian Crisis, fundusz Madad) o państwa Bałkanów Zachodnich ${ }^{24}$. Pierwotnie KE dedykowała tę pomoc przede wszystkim Syrii i państwom ościennym, nie wspominając o państwach bałkańskich.

Ze względu na utrzymującą się wysoką falę migracyjną zainteresowanie UE sytuacją na Bałkanach Zachodnich nie słabło w kolejnych latach. W 2016 r. przewodniczący KE Jean-Claude Juncker oraz przewodniczący Rady Europejskiej Donald Tusk odbyli wizyty we wszystkich państwach Bałkanów Zachodnich, pokazując w ten sposób wzmożoną aktywność UE w regionie. Wizyty te miały na celu w głównej mierze opanowanie kryzysu uchodźczego na migracyjnym szlaku zachodniobałkańskim ${ }^{25}$.

Kolejnym istotnym krokiem wskazującym na większe zaangażowanie UE w Bałkanach Zachodnich było przedstawienie przez KE nowej strategii polityki UE wobec Bałkanów Zachodnich (dokument z 6 lutego 2018 r.). Nazwa „strategia na rzecz wiarygodnej perspektywy rozszerzenia dla Bałkanów Zachodnich oraz zwiększonego zaangażowania UE w tym regionie" podkreśla dwa najważniejsze cele UE. W strategii tej KE uzależniła akcesję poszczególnych państw Bałkanów Zachodnich od osiąganych przez nie wyników, dostosowanych indywidualnie do każdego państwa ${ }^{26}$.

Komisja przedstawiła również w strategii sześć inicjatyw przewodnich na rzecz: umocnienia praworządności, zacieśnienia współpracy w dziedzinie bezpieczeństwa i migracji, zwiększonego wsparcia rozwoju gospodarczo-społecznego, poprawy połączeń transportowych i energetycznych ${ }^{27}$. Kluczowa dla omawianej problematyki była inicjatywa dotycząca zacieśnienia współpracy $\mathrm{w}$ dziedzinie bezpieczeństwa i migracji za pomocą wspólnych zespołów oraz Frontexu. Unia zobowiązała się także do zwiększenia finansowania w ramach Instrumentu Pomocy Przedakcesyjnej (IPA) do 2020 r.

Bałkany Zachodnie otrzymały wówczas już w latach 2011-2017 wsparcie w wysokości ok. 9 mld euro, zaś na 2018 r. zaplanowano dodatkowe wsparcie w wysokości 1,07 mld euro $^{28}$. W nowej strategii zaproponowano zastosowanie podejścia integracji

23 Council of the European Union, Outcome of the Council Meeting, $3439^{\text {th }}$ Council meeting. General Affairs, Brussels, 15 XII 2015, s. 4, [online] https://www.consilium.europa.eu/media/23049/ st15313en15_v3.pdf.

24 European Commission, Commission Decision of 21.12.2015 Amending Decision C(2014) 9615 Final on the Establishment of a European Union Regional Trust Fund in Response to the Syrian Crisis, „the Madad Fund", C(2015) 9691 final, s. 2.

25 M. Szpala, Nowe otwarcie..., s. 1.

26 Komisja Europejska, Wiarygodna perspektywa rozszerzenia dla Batkanów Zachodnich oraz zwiększone zaangażowanie UE w tym regionie, $\operatorname{COM}(2018)$ 65, 6 II 2018, s. 3-9.

27 Tamże, s. 20.

28 Tamże, s. 18. 
sektorowej, która miała pozwolić na ściślejsze powiązania w poszczególnych sektorach gospodarki - ale z drugiej strony nie oferowała ona żadnych instrumentów kontrolujących praworządność ${ }^{29}$.

Najważniejszym wydarzeniem podkreślającym zaangażowanie UE w omawianym regionie był szczyt UE-Bałkany Zachodnie, który odbył się 17 maja 2018 r. w Sofii, pierwszy tego typu od 2003 r. Wzięli w nim udział przywódcy państw członkowskich UE oraz sześciu partnerów zachodniobałkańskich: Albanii, Bośni i Hercegowiny, Serbii, Czarnogóry, Byłej Jugosłowiańskiej Republiki Macedonii (obecnie Macedonia Północna) oraz Kosowa. Podczas szczytu przewodniczący Rady Europejskiej Donald Tusk powiedział: Nie widzę innej przysztości dla Batkanów Zachodnich niż UE. Nie ma żadnej innej alternatywy, nie ma planu B. Batkany Zachodnie sa integralna cześsia Europy i należa do naszej wspólnoty ${ }^{30}$.

Na szczycie uzgodniono i przyjęto deklarację sofijską, a także program działań priorytetowych z Sofii, w którym określono nowe metody zacieśniania współpracy z regionem. Punkt 10 deklaracji został poświęcony wyzwaniom związanym z bezpieczeństwem oraz ograniczaniu nielegalnych przepływów migracyjnych. Unia Europejska wyraziła zadowolenie z dotychczasowej współpracy oraz zasygnalizowała konieczność dalszego jej rozwoju. W punkcie 12 deklaracji podkreśliła także konieczność podjęcia zdecydowanych działań przeciwko handlowi i przemytowi ludzi, a w kolejnym punkcie wyraziła potrzebę pogłębienia współdziałania w obrębie wspólnej polityki zagranicznej i bezpieczeństwa (WPZiB) ${ }^{31}$.

W programie działań z Sofii, stanowiącym załącznik do wyżej opisanej deklaracji, drugim działaniem priorytetowym było większe zaangażowanie w kwestiach bezpieczeństwa i migracji. Wyodrębniono w nim cele związane z polityką imigracyjną, azylową i ochroną granic zewnętrznych, takie jak: zacieśnianie współpracy w zakresie zarządzania migracją i granicami, kontynuacja pogłębiania współpracy między oficerami łącznikowymi oddelegowanymi przez UE (KE i Frontex), państwami członkowskimi oraz właściwymi organami partnerów z Bałkanów Zachodnich ${ }^{32}$. Podczas posiedzenia zaplanowano, że kolejny szczyt UE-Bałkany Zachodnie odbędzie się podczas prezydencji chorwackiej w $2020 \mathrm{r}$.

Innym działaniem UE wobec Bałkanów Zachodnich w kontekście kryzysu migracyjnego było zwiększenie pomocy humanitarnej, szczególnie dla Bośni i Hercegowiny. Od 2018 r. UE przeznaczyła dodatkowe środki z pomocy humanitarnej na zapewnienie pomocy nadzwyczajnej, realizowanej przez międzynarodowe organizacje humanitarne. Pomoc przeznaczona była na potrzeby uchodźców i migrantów

29 M. Szpala, Nowe otwarcie..., s. 1.

30 Wystapienie Donalda Tuska po szczycie UE-Batkany Zachodnie, 17 V 2018, [online] https://www. consilium.europa.eu/pl/press/press-releases/2018/05/17/remarks-by-president-donald-tusk-after-the-eu-western-balkans-summit/, 20 XI 2019.

31 Deklaracja $z$ Sofii, 17 V 2018, s. 2, [online] https://www.consilium.europa.eu/media/34797/sofia-declarationpl.pdf, 25 XI 2019.

32 Tamże, s. 4-5. 
obecnych w szczególności w regionie Una-Sana w północno-zachodniej części Bośni i Hercegowiny ${ }^{33}$.

Warto podkreślić, że wzrost zaangażowania UE w Bałkanach Zachodnich przejawiał się również w rozwijaniu kompetencji operacyjnych Frontexu. W listopadzie 2019 r. Parlament Europejski i Rada Unii Europejskiej przyjęły rozporządzenie, które wzmocniło Europejską Straż Graniczną i Przybrzeżną oraz dało jej możliwość prowadzenia działań i rozmieszczania personelu w krajach nienależących do UE, o ile wcześniej Frontex zawrze z nimi umowę statusową ${ }^{34}$.

Współpraca z państwami trzecimi jest realizowana w ramach europejskiej koncepcji zintegrowanego zarządzania granicami, która winna być realizowana na czterech poziomach: poprzez działania w państwach trzecich, działania z ościennymi państwami trzecimi, środki kontroli granicznej oraz działania w strefie Schengen.

W listopadzie 2019 r. weszła w życie umowa z Serbią, która daje możliwość wspierania tego kraju w zarządzaniu jego granicami za jego zgodą. Dzięki temu Frontex nabył nowe możliwości - prowadzenia wspólnych operacji, rozmieszczania zespołów funkcjonariuszy na serbskich obszarach przygranicznych oraz udzielania większej pomocy techniczno-operacyjnej na granicach. Nowe zdolności operacyjne mają poprawić skuteczność w zwalczaniu nielegalnej migracji i przestępczości zorganizowanej ${ }^{35}$.

Podobne umowy statusowe podpisano także z Macedonią Północną, Bośnią i Hercegowiną, Albanią oraz Czarnogórą. Umowy z Macedonią Północną oraz Bośnią i Hercegowiną oczekują obecnie (grudzień 2019 r.) na wejście w życie ${ }^{36}$. Jedynym partnerem z Bałkanów Zachodnich, z którym takiej umowy nie negocjowano, jest Kosowo.

Innym istotnym instrumentem wykorzystanym przez UE podczas kryzysu migracyjnego wobec Bałkanów Zachodnich był tzw. proces berliński. Tę inicjatywą wspierającą współpracę regionalną Bałkanów Zachodnich i uzupełniającą politykę rozszerzenia UE zainicjowały Niemcy na szczycie w 2014 r. w Berlinie. W procesie uczestniczą państwa Bałkanów Zachodnich: Albania, Bośnia i Hercegowina, Czarnogóra, Kosowo oraz Macedonia Północna, a także niektóre państwa członkowskie UE, takie jak: Austria, Bułgaria, Chorwacja, Francja, Grecja, Niemcy, Polska, Słowenia, Wielka Brytania i Włochy, oraz KE. Na drugim szczycie procesu berlińskiego zorganizowanym

33 Komisja Europejska, Komunikat Komisji do Parlamentu Europejskiego, Rady Europejskiej i Rady. Sprawozdanie z postępów w realizacji Europejskiego programu w zakresie migracji, $\operatorname{COM}(2019) 481,16 \mathrm{X}$ 2019, s. 9-10.

34 Rozporzadzenie Parlamentu Europejskiego i Rady (UE) 2019/1896 z dnia 13 listopada 2019 r. w sprawie Europejskiej Straży Granicznej i Przybrzeżnej oraz uchylenia rozporządzeń (UE) nr 1052/2013 i (UE) 2016/1624, Dz.U. UE, L 295/1, 14 XI 2019, s. 1.

35 Council of the European Union, Status Agreement between the European Union and the Republic of Serbia on Actions Carried Out by the European Border and Coast Guard Agency in the Republic of Serbia, Brussels, 21 I 2019, s. 1, [online] https://data.consilium.europa.eu/doc/document/ST-15579-2018-REV-1/en/pdf, 19 XII 2019.

36 Rada Unii Europejskiej, Zarządzanie granicami: UE podpisuje umowe o wspótpracy z Serbia, 19 XI 2019, [online] https://www.consilium.europa.eu/pl/press/press-releases/2019/11/19/border-management-eu-signs-agreement-with-serbia-on-european-border-and-coast-guard-cooperation/, 19 XII 2019. 
w Wiedniu 27 sierpnia 2015 r. migracja na szlaku zachodniobałkańskim stanowiła jedną z głównych dyskutowanych kwestii ${ }^{37}$. Podobnie było podczas kolejnych szczytów w Paryżu (2016) 38 i w Trieście (2017) ${ }^{39}$. Na szczycie w Londynie (2018) zagadnienie migracji było mniej kluczowe i omówiono je razem z innymi problemami związanymi z bezpieczeństwem. Podobnie postąpiono na szczycie w Poznaniu (2019), podczas którego przywódcy i ministrowie rozmawiali o postępach współpracy w dziedzinie bezpieczeństwa między Bałkanami Zachodnimi a UE, w tym walki ze zorganizowaną przestępczością, natomiast migracji nie poświęcono osobnego punktu ${ }^{40}$.

\section{KONKLUZJE}

Podsumowując te rozważania, należy podkreślić, że założenie, iż kryzys migracyjny przyczynił się do zwiększenia zaangażowania UE w Bałkanach Zachodnich, okazało się jedynie częściowo prawdziwe. Podczas kryzysu migracyjnego nastąpiło istotne ożywienie w relacjach między UE a Bałkanami Zachodnimi, jednak nie miało ono bezpośredniego przełożenia na przyspieszenie procesów akcesyjnych. Przyczyniło się natomiast do poprawy współpracy operacyjnej w polityce migracyjnej i azylowej oraz do ochrony granic zewnętrznych. Kryzys migracyjny doprowadził także do wzrostu nastrojów eurosceptycznych w Bałkanach Zachodnich, ponieważ pokazał słabość UE, jej problemy w zapewnieniu bezpieczeństwa i stabilności ${ }^{41}$ oraz krótkowzroczność jej polityki w regionie; działania UE w 2015 r. były prowadzone ad hoc, jednak z drugiej strony trudno było przewidzieć i przygotować się na presję migracyjną o takiej skali ${ }^{42}$.

Strategię wobec Bałkanów Zachodnich KE wprowadziła dopiero w 2018 r. Stanowiło to próbę zmiany perspektywy i wyznaczenia długoterminowych celów strategicznych w regionie. Sposób, w jaki odniesiono się do Macedonii Północnej i Albanii, z którymi nie rozpoczęto negocjacji akcesyjnych $\mathrm{w}$ zapowiadanym terminie, pokazał, że prawdziwymi celami UE w regionie były eksternalizacja ochrony granic zewnętrznych

37 Final Declaration by the Chair of the Vienna Western Balkans Summit, 27 VIII 2015, s. 3, [online] https://berlinprocess.info/wp-content/uploads/2017/12/Final-Declaration-by-the-Chair-of-the-Vienna-Western-Balkans-Summit.pdf, 20 XII 2019.

38 Final Declaration by the Chair of the Paris Western Balkans Summit, 4 VII 2016, s. 6-7, [online] https://berlinprocess.info/wp-content/uploads/2017/11/Final-Declaration-by-the-Chair-of-the-Paris-Western-Balkans-Summit.pdf, 19 XII 2019.

39 Western Balkans Summit. Trieste. Declaration by the Italian Chair, 12 VII 2017, s. 9-10, [online] https://berlinprocess.info/wp-content/uploads/2017/11/Declaration-by-the-Italian-Chair.pdf, 19 XII 2019.

40 Western Balkans Summit Poznań. Chair's Conclusions, 5 VII 2019, s. 10, [online] https://berlinprocess.info/wp-content/uploads/2019/07/chairs_conclusions.pdf, 19 XII 2019.

41 A. Ivlevs, R.M. King, To Europe or Not to Europe? Migration and Public Support for Joining the European Union in the Western Balkans, „International Migration Review” 2020, Vol. 54, nr 2, s. 3.

42 E. Cocco, Where Is the European Frontier..., s. 295. 
oraz utworzenie strefy buforowej, która miałaby lepiej chronić organizację przed kolejną falą migracyjną. Takie traktowanie partnerów z Bałkanów Zachodnich może przyczynić się w dłuższej perspektywie do spadku zaufania wobec UE i wzrostu strategicznej pozycji innych aktorów, dla których region ten stanowi atrakcyjną przestrzeń do powiększania strefy wpływów.

\section{BIBLIOGRAFIA}

Antosiewicz M., Zaczyna się nowa fala migracji do Europy. Imigranci wrócili na szlak batkański, Newsweek, 9 VII 2019, [online] https://www.newsweek.pl/swiat/nowa-fala-migracjido-europy-imigranci-wrocili-na-szlak-balkanski/49k700p.

Bujwid-Kurek E., Państwa o proweniencji jugostowiańskiej w procesie rozszerzania Unii Europejskiej - refleksja politologiczna, „Politeja” 2019, Vol. 15, nr 54, https://doi.org/10.12797/ politeja.15.2018.54.01.

Buzan B., Waever O., Regions and Powers. The Structure of International Security, Cambridge 2003, Cambridge Studies in International Relations, 91.

Cocco E., Where Is the European Frontier? The Balkan Migration Crisis and Its Impact on Relations between the EU and the Western Balkans, „European View” 2017, Vol. 16, nr 2, https://doi.org/10.1007/s12290-017-0471-5.

Council of the European Union, Council Conclusions on the Western Balkans, 2518th Council meeting - External Relations, Luxembourg, 16 VI 2003.

Council of the European Union, Outcome of the Council Meeting, 3439th Council meeting. General Affairs, Brussels, 15 XII 2015, [online] https://www.consilium.europa.eu/ media/23049/st15313en15_v3.pdf.

Council of the European Union, Status Agreement between the European Union and the Republic of Serbia on Actions Carried Out by the European Border and Coast Guard Agency in the Republic of Serbia, Brussels, 21 I 2019, [online] https://data.consilium.europa.eu/doc/ document/ST-15579-2018-REV-1/en/pdf.

Deklaracja z Sofii, 17 V 2018, [online] https://www.consilium.europa.eu/media/34797/ sofia-declaration_pl.pdf.

Dymarski M., „Miękkie podbrzusze Europy” - Batkany w nowoczesnych stosunkach międzynarodowych, [w:] Batkany. Przesztość - teraźniejszość - przysztość, red. M. Podolak, Lublin 2013, Wprowadzenie do Studiów Wschodnioeuropejskich, t. 1.

European Commission, Meeting on the Western Balkans Migration Route: Leaders Agree on 17-Point Plan of Action, 25 X 2015, [online] https://ec.europa.eu/commission/presscorner/ detail/en/IP_15_5904.

Final Declaration by the Chair of the Paris Western Balkans Summit, 4 VI 2016, [online] https:// berlinprocess.info/wp-content/uploads/2017/11/Final-Declaration-by-the-Chair-of-the-Paris-Western-Balkans-Summit.pdf.

Final Declaration by the Chair of the Vienna Western Balkans Summit, 27 VIII 2015, [online] https://berlinprocess.info/wp-content/uploads/2017/12/Final-Declaration-by-the-Chair-of-the-Vienna-Western-Balkans-Summit.pdf. 
Greider A., Outsourcing Migration Management: The Role of the Western Balkans in the European Refugee Crisis, 17 VIII 2017, [online] http://www.migrationpolicy.org/article/ outsourcing-migration-management-western-balkans-europes-refugee-crisis.

European Commission, Commission Decision of 21.12.2015 Amending Decision C(2014) 9615 Final on the Establishment of a European Union Regional Trust Fund in Response to the Syrian Crisis, the "Madad Fund”, C(2015) 9691 final.

Ivlevs A., King R.M., To Europe or Not to Europe? Migration and Public Support for Joining the European Union in the Western Balkans, „International Migration Review” 2020, Vol. 54, nr 2, https://doi.org/10.1177/0197918319844176.

Komisja Europejska, Komunikat Komisji do Parlamentu Europejskiego, Rady Europejskiej i Rady. Sprawozdanie z postępów $w$ realizacji Europejskiego programu $w$ zakresie migracji, $\operatorname{COM}(2019)$ 481, 16 X 2019.

Komisja Europejska, Wiarygodna perspektywa rozszerzenia dla Batkanów Zachodnich oraz zwiększone zaangażowanie UE w tym regionie, COM(2018) 65, 6 II 2018.

Koźbiał K., Unia Europejska jako czynnik stabilizacyjny na Batkanach. Stan obecny i wyzwania na przysztość, [w:] Unia Europejska jako wspótczesny aktor stosunków międzynarodowych, red. J. Knopek, Toruń 2009.

Migratory Map, Frontex, [online] https://frontex.europa.eu/along-eu-borders/migratory-map/. Migratory Routes, Frontex, [online] https://frontex.europa.eu/along-eu-borders/migratoryroutes/western-balkan-route/.

Olszewski P., Batkany Zachodnie w polityce Unii Europejskiej, „Myśl Ekonomiczna i Polityczna” 2010, nr 1(28).

Paszkiewicz J., Wspótpraca regionalna na Batkanach Zachodnich z perspektywy Unii Europejskiej. Przestanki i przeszkody, [w:] Batkany Zachodnie. Między przesztością a przysztością, red. P. Chmielewski, S.L. Szczesio, Łódź 2013, Batkany na Przetomie XX/XXI Wieku, 3.

Podgórzańska R., Kryzys migracyjny w Unii Europejskiej z perspektywy Batkanów Zachodnich, „Rocznik Integracji Europejskiej” 2018, nr 11, https://doi.org/10.14746/rie.2017.11.21.

Population Trends, UNHCR, [online] https://www.unhcr.org/see/about-us/populationtrends.

Rada Unii Europejskiej, Zarządzanie granicami: UE podpisuje umowe o wspótpracy z Serbia, 19 XI 2019, [online] https://www.consilium.europa.eu/pl/press/press-releases/2019/11/19/ border-management-eu-signs-agreement-with-serbia-on-european-border-and-coast-guard-cooperation/.

Rozporzadzeniem Parlamentu Europejskiego i Rady (UE) 2016/1624 z dnia 14 września 2016 r. w sprawie Europejskiej Straży Granicznej i Przybrzeżnej oraz zmieniajace rozporzadzenie Parlamentu Europejskiego i Rady (UE) 2016/399 i uchylajace rozporzaddzenie (WE) nr 863/2007 Parlamentu Europejskiego i Rady, rozporzadzenie Rady (WE) nr 2007/2004 i decyzje Rady 2005/267/WE, Dz.U. UE, L 251, 16 IX 2016.

Rozporzadzenie Parlamentu Europejskiego i Rady (UE) 2019/1896 z dnia 13 listopada 2019 r. w sprawie Europejskiej Straży Granicznej i Przybrzeżnej oraz uchylenia rozporządzeń (UE) nr 1052/2013 i (UE) 2016/1624, Dz.U. UE, L 295, 14 XI 2019.

Sokołowska P., RFN-Unia Europejska i Pakt Stabilności dla Europy Potudniowo-Wschodniej, „Rocznik Integracji Unii Europejskiej” 2008, nr 2, https://doi.org/10.14746/rie.2008.2.13. 
Szpala M., Nowe otwarcie w stosunkach Unia Europejska - Batkany Zachodnie, „Komentarze OSW" 2018, nr 267.

Western Balkans Summit. Trieste. Declaration by the Italian Chair, 12 VII 2017, [online] https:// berlinprocess.info/wp-content/uploads/2017/11/Declaration-by-the-Italian-Chair.pdf.

Western Balkans Summit Poznań. Chair's Conclusions, 5 VII 2019, [online] https://berlinprocess.info/wp-content/uploads/2019/07/chairs_conclusions.pdf.

Wystąpienie Donalda Tuska po szczycie UE-Batkany Zachodnie, 17 V 2018, [online] https:// www.consilium.europa.eu/pl/press/press-releases/2018/05/17/remarks-by-presidentdonald-tusk-after-the-eu-western-balkans-summit/.

Mgr Wawrzyniec BANACH - absolwent studiów magisterskich w Instytucie Nauk Politycznych Stosunków Międzynarodowych na Uniwersytecie Jagiellońskim (2016), doktorant w Katedrze Studiów nad Procesami Integracyjnymi w Instytucie Nauk Politycznych i Stosunków Międzynarodowych UJ. Obszar jego zainteresowań badawczych: instytucje Unii Europejskiej, polityka bezpieczeństwa, sekurytyzacja, eksternalizacja, migracje międzynarodowe, polityka regionalna UE. 